\title{
CHAPTER
}

\section{Quality of Work in the Cleaning Industry: A Complex Picture Based on Sectoral Regulation and Customer-Driven Conditions}

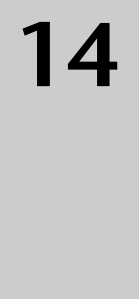

\author{
Vassil Kirov and Monique Ramioul
}

The cleaning sector in Europe is experiencing job growth because of the continuous trend of outsourcing and at present accounts for almost 4 million jobs in the European Union (EU). Working in the cleaning industry involves high risks due to precarious employment conditions, poor job quality and limited opportunities for adequate representation at company level. A combination of factors shaping the employment relationship lie at the root of this high-risk configuration, such as the fragmentation of the workforce over different client sites, the impact of cost reduction strategies of clients on wages and job content, and the growing rationalization of work.

Yet it appears that in several EU countries, as well as at European level, sectoral social dialogue structures and practices succeed in mitigating some of the negative effects for employees. Guaranteed employment conditions in case a client's site is transferred to another service provider, joint actions promoting socially acceptable working times, attempts to influence public procurement and agreements on new work methods reducing health and safety risks are marked examples of such sectoral collective bargaining outcomes. This demonstrates how working conditions and employment relations in service sectors where workers are particularly vulnerable may be improved through sectoral agreements. Such relatively consensual sectoral social dialogue, which is observed in a number of EU countries, is rooted in joint interests among the social partners to combat unfair competition, on the one hand, and to negotiate profitable contracts with clients that are beneficial to both the service provider and the workers, on the other. Cross-country sectoral 
convergences in employment regulation have previously been observed in other sectors by Katz and Darbishire (1999). Combined with the general observation that working conditions between sectors increasingly diverge within countries, among other things as a result of outsourcing strategies (Flecker 2010), this cross-country convergence endorses previous critics of varieties-of-capitalism arguments that assume coherent national systems of work and employment relations.

Nevertheless, it comes to the fore that sectoral regulation does not prevent persistent variations in employment conditions within companies in the different countries, even in subsidiaries of the same transnational firms. This suggests first that, even in a context of globalized corporate strategies and sectoral regulation, national systems still have an influence. Second, as we will argue in this chapter, the triangular relationship 'employer-client-worker', which is characteristic for this type of externalized service, provides a key explanation of the organizational varieties. This effect may not have been sufficiently examined in previous institutional comparative research on employment regulation. In the triangular relationship in service work, the employment relationship and job quality are shaped not only by the service provider, as the formal employer, but also by the local client, at whose site the work is actually carried out. Both the limitations for sectoral unions to effectively influence employment conditions at the client's site and the powerful sectoral social dialogue rooted in the alliance between the service providers and the trade unions can be explained by this triangular relationship.

In this chapter, we combine different theoretical perspectives to gain a deeper understanding of this complex configuration of employment regulation and its impact on the job quality of office cleaners. This is done on the basis of a combination of investigations into sectoral social dialogue in three European countries as well as case studies in a number of large multinational service providers. We first summarize the theoretical debates to which we turn to understand the observations. In a second section, the empirical research is described. The data used in this chapter are based on the cleaning industries in three countries: Austria, Belgium and Norway. In the third section, we describe the office cleaning sector in the three countries and some recent corporate strategies while in the fourth section we analyse the similarities and differences in employment regulation. In the conclusion, we summarize key findings and discuss how the chapter contributes to the theoretical literature. 


\section{Convergence and Divergence in Employment Regulation and the Triangular Relationship in Service Work}

The varieties-of-capitalism (VoC) approach has been developed on the basis of previous theories such as the social-systems-of-production approach (Hollingsworth and Boyer 1997) and national business systems (Whitley 1992). The social-systems-of-production approach argues that market and other coordination mechanisms of a country or a region are integrated in a social configuration that includes the industrial relations system, the training structure, the firm's governance structure and so on (Hollingsworth and Boyer 1997:2). The authors argue that countries vary in types of coordination mechanisms and social systems of production (ibid. p. 36). The national business systems are 'particular arrangements of hierarchy-market relations which become institutionalized and relatively successful in particular contexts' (Whitley 1992:6). According to Whitley (1992:37) such variations in the national homogeneity and distinctiveness of business systems and dominant institutions emphasize the contingent nature of national hierarchy-market configurations.

The VoC approach has become a key institutional framework for the study of comparative capitalism following the publication of Hall and Soskice's work (Hall and Soskice 2001). They suggest that 'also there are variations within each group, a pronounced clustering is evident' (Hall and Soskice 2001:19). Other literature on employment regulation, however, has observed increasing within-country variation. Katz and Darbishire (1999) examine changes in employment practices in seven industrialized countries (with a focus on the automotive and telecommunications industries) since the 1980s and find a trend of growing divergences within national employment systems combined with striking commonalities (convergence) across countries that are very different historically and economically. In all countries, they observe trade union decline and a decentralization of collective bargaining as well as important changes in work organization, such as the introduction of teamwork and of modern HRM practices. As a result of declining union power, the seven countries studied all faced growing income inequality and employment insecurity. In addition, the authors also observed growing divergences within unionized sectors, which they explain by the spread of specific practices at workplace level. The outcomes for workers and the extent of the within-country divergences, however, still appeared to be influenced by national institutions (ibid.). 
Other authors who have discussed internal heterogeneity include Herrigel (1996), Quack and Morgan (2000), Dörrenbächer (2002), and Herrigel and Zeitlin (2010). Already in 1996 Herrigel developed the argument that the focus on large companies renders the image of the development of the German industrial economy incomplete (Herrigel 1996:19) for not taking into account regional systems of small and medium enterprises, their interrelations with large firms, and so on. In his recent book Manufacturing Possibilities: Creative Action and Industrial Recomposition in the United States, Germany, and Japan (2010) Herrigel develops this argument further, criticizing the VoC approach. Based on qualitative research in ten German MNCs that have invested in Hungary during the 1990s, Dörrenbächer (2002) criticizes some central arguments of the national business system approach towards corporate internationalization, especially the notion of a rather strong and uniform country-of-origin effect. Herrigel and Zeitlin (2010) accentuate their critique of VoC by pointing out dynamic governance processes whereby actors at the sectoral or regional level jointly develop strategies and practices to tackle more effectively the problems they are confronted with. Such creative problem-solving efforts lead to recompositions of social relations within the economy and contribute to 'differences in industrial practice across various national (and regional) political economies over time' (Herrigel and Zeitlin 2010:7). Rather than emphasizing the path dependency of institutional arrangements as is done in VoC, such a dynamic approach accounts for variety and change in political-economic practice.

Based on a comparative analysis of employment regulation in a number of industries, Flecker $(2006,2010)$ finds that work and employment conditions are becoming increasingly diverse, not only at the global level but also within countries, within sectors and even within organizations. These growing divergences are related to processes of contractual outsourcing and spatial relocation, which are defined as types of value chain restructuring: 'Here, fragmentation means that different employment relations and conditions apply to workers carrying out tasks that were previously, or partially still are, performed within the client organization' (Flecker 2010:16). In general, the argument is that outsourcing contributes to divergences because the receiving sectors mostly have lessinstitutionalized industrial relation systems and are consequently less likely to be covered by sectoral collective agreements (Flecker 2010). However, Flecker finds that the within-country divergences are also influenced by national employment systems. These can mitigate differences in employment conditions when they provide relatively homogeneous and comprehensive labour regulations at the national level. But even in employment systems with a relatively high degree of centralization, 
marked differences between collective agreements may exist and boost externalization of work (Flecker 2010:17).

Flecker further emphasizes that employment systems, especially when they provide comprehensive regulation of work at the national and sectoral levels, may be able to cover the externalized workforce, contribute to the stabilization of industrial relations in new and growing sectors and lead eventually to the 'normalization' of working conditions. These sectoral collective agreements, however, contain serious concessions and offer lower levels of protection (lower wages and more flexibility) as compared with previous standards. This leads to an increase of within-country differentiations in employment conditions.

In sum, it becomes increasingly difficult to support the argument of coherent and unified national systems of work and employment. There seem on the contrary to be indications of diverging employment conditions within countries - due to, among other things, continuous processes of externalization leading to new sectoral regulations. These may diverge from existing national standards or from those prevailing in the sectors of origin, but may also lead to a better outcome as compared with what would be achievable solely at the company level. To the extent that such collective bargaining at the sectoral level can be observed in countries with differing national employment systems, this suggests a convergence of sectoral employment regulation across countries. Yet, it appears that this sectoral regulation does not prevent persistent variations in working conditions within companies across the different countries. Here, the specific characteristics of service work industries, more precisely the triangular relationship, can provide an additional explanation as to how working conditions are shaped. This structural feature of a wide range of services, involving the fact that some dimensions of the job are determined by the client, may not have been sufficiently addressed in institutional approaches. Taking account of the scale and scope of the externalization of services as a key element in the tertiarization of postfordist economies (Vidal 2013), it is useful to consult the literature that attempts to specify the employment regulation from this triangular perspective.

There is an understanding that service work was marginalized and neglected in sociology up until the 1990s. Recently, however, sociologists of work, especially those in the labour process tradition, have increasingly made it their key focus and during the last decade there has been a growing corpus of literature focused on service work. As Korczynski (2009) concludes, 'Studies of service work have now become the empirical mainstream in the sociology of work' (2009:952). Among the dominant topics that have come to rectify this 'historical neglect of service work' is the 
triangular relationship between managers, workers and clients. According to Vosko (1997), the triangular employment relationship creates serious tension within prevailing regulatory regimes associated with the standard employment relationship. Already in 2000, Korczynski et al. considered the nature of control and the role of consumers in service work (for example in call centre services) (Korczynski et al. 2000). Bolton and Houlihan (2010) point out that it is widely recognized that the growth of service work has introduced the customer as a third and, in many accounts, powerful party to conceptions of the employment relationship. According to Lopez (2010), the triangular power relations between workers, managers and clients or customers dominate the experience of work more than ever. Leidner's (1996) notion of three-way interest alliances made a key contribution by reframing the client or customer as not simply an antagonist but also potentially as an ally of workers and of managers (Leidner 1996). In this chapter, we argue that the triangular relationship is also a relevant framework for a whole range of on-site services and that it is reflected in strong, compensating alliances at sectoral level.

The triangular relationship puts the organization where the service work activities are taking place at the centre of the analysis. This may contribute to understanding variations in outcomes for workers between countries and companies. Cleaning is typically one of those jobs where a worker is employed at a site which is not the place where his or her employer resides and consequently the control of work is distributed between the employer and the local manager of the client company. The employee has a contract with the cleaning company that settles the wages and contractual conditions, but most of the operational aspects of the job, including working hours, work environment, health-and-safety risks and so on are determined at the client's site. Hence, this triangular relationship strongly impacts on job quality. The triangular relationship is also a key determinant for the establishment of collectives and for generating opportunities for shopfloor collective action (Denis 2008). The fragmentation and distribution of the workforce over different sites, the temporary dimension of the allocation of workers to those sites, with regular shifting to new sites, the widespread use of part-time work and the absence of local employee representatives (who mostly have no access to clients' sites) are the main reasons why collective action at company or site level is limited and difficult to organize.

The question is now as follows: At what levels and by what mechanisms are job quality and employment regulated in the different countries under study and why? 
Vassil Kirov and Monique Ramioul

Table 14.1 Interviews with stakeholders from the cleaning industry in WALQING

\begin{tabular}{lccccc}
\hline & $\begin{array}{c}\text { Trade } \\
\text { unions }\end{array}$ & $\begin{array}{c}\text { Employers' } \\
\text { associations }\end{array}$ & $\begin{array}{c}\text { Public } \\
\text { authorities }\end{array}$ & $\begin{array}{c}\text { Other } \\
\text { stake- } \\
\text { holders }\end{array}$ & $\begin{array}{c}\text { Total number } \\
\text { of interviews } \\
\text { per country }\end{array}$ \\
\hline Austria & 1 & 2 & 3 & - & 6 \\
Belgium & 3 & 2 & - & 1 & 6 \\
Norway & 2 & 2 & - & 1 & 5 \\
EU level & 1 & 1 & - & 1 & 3 \\
Total & 9 & 8 & 3 & 3 & 23 \\
\hline
\end{tabular}

\section{Research Method}

The chapter is based on the research carried out in the framework of a large comparative European project investigating work and life quality in new and growing jobs. ${ }^{1}$ Based on a quantitative analysis of employment trends in the EU (Vandekerckhove et al. 2010), a number of sectors, including office cleaning, were selected to be studied in depth. In the analysis of office cleaning in Austria, Belgium and Norway, the data come from sectoral reports on stakeholder strategies based on interviews carried out at European and country level with employers' representatives and trade union organizations. As depicted in Table 14.1, a total of 23 interviews were carried out.

In addition, 10 company case studies were carried out in the cleaning industry (Holtgrewe and Sardadvar 2012) and 105 cleaners in the three countries were interviewed (Hohnen 2012).

\section{The Cleaning Sector in Europe}

\section{Setting the Scene}

Overall, the cleaning industry is growing in Europe. According to the European Federation of Cleaning Industries (EFCI), commercial cleaning represents one of the most dynamic areas of corporate services, with more than 158000 cleaning contractors employing 3.75 million employees across Europe (about 1.8 per cent of total employment in the European Union) in 2010 and generating turnover of nearly $€ 62$ billion (EFCI 2010). Market penetration (defined as the share of cleaning services 
Table 14.2 Cleaning industry in examined countries

\begin{tabular}{llll}
\hline & Austria & Belgium & Norway \\
\hline Number of employees & $51003(2008)$ & 46237 & $56000(2008)$ \\
$\%$ of women & $65.3 \%$ & n.a. & $80 \%$ \\
$\%$ of part-time work & $16.4 \%$ men & About $70 \%$ & $10 \%$ men \\
& $66 \%$ women & & $40 \%$ women \\
\hline
\end{tabular}

Source: National Reports (WALQING Social Partnership Series, http://www.walqing.eu/index.php?id=64)

contracted out to specialized cleaning companies) by cleaning companies is still growing and is now at a level of about 63.8 per cent in general and over 80 per cent in countries such as Austria or the Netherlands. This means that this process of outsourcing is reaching its limits and the market is becoming saturated.

In terms of employment, the sector is dominated by a number of large, mostly multinational firms. A few large companies, representing about 1.4 per cent of the total number of enterprises, contribute to almost half of the total turnover in the industry. Next to this formal segment of big and mostly well-regulated companies there are very many, very volatile small and micro businesses. Market entry is relatively easy and 74 per cent of companies employ less than 10 people. Micro companies have a bad reputation because they often operate on the edge of illegality, offer undeclared work and precarious contracts, apply practices of unpaid overtime, provide no training and resist any form of formal social dialogue structures (EFCI 2010). Table 14.2 highlights some basic characteristics of the sector for the countries involved.

The two main vulnerable groups in the sector are migrants and mothers of young children. In Austria, nearly two-thirds of the workers were women and in Norway this climbed to 80 per cent. Almost half of the workforce in Austria was non-Austrian, with a sizeable majority of immigrants coming from countries outside the EU. In Norway as well the sector employs a high percentage of immigrant workers. In Belgium, the great majority of workers were working part-time.

\section{Job Quality in Office Cleaning}

Across the cases in the three countries, similar risks and vulnerabilities were reported. The stakeholders interviewed described the work in cleaning as physically demanding, mostly unskilled low-wage work that is made worse by the prevalence of socially difficult working hours. As one Austrian trade union respondent defined it, motivation in cleaning is at 
the lower end and workers are mostly 'in it for the money' (Holtgrewe and Saradvar 2011). Cleaning offices in administrative sectors (such as in banks) is generally preferred over cleaning offices in manufacturing companies, where the work is harder and cleaners report that they get less respect from the client's employees. Another common issue is that the most vulnerable groups of cleaners are those working for 'junk enterprises' (Torvatn 2011). These companies employ migrant workers of different legal statuses and vulnerable people who for various reasons have trouble entering the workforce and have somehow been excluded from the regular job market (returning from long-term sickness, alcohol and/or drug problems, and so on).

Some specific characteristics of office cleaning contribute negatively to the quality of the work. The first concerns the specific working hours, resulting from the need to adapt to the operating hours of the client, while the second relates to the widespread use of part-time work. With some exceptions, cleaning services are predominantly performed outside the usual periods of occupation of the premises. This is particularly true for office cleaning, but also applies to technical cleaning and to commercial premises or buildings with public access. According to Uni-Europa, ${ }^{2}$ the average working day distribution consists of 26 per cent of work in the early morning and 43 per cent of work in the late afternoon. There are, however, significant differences between EU countries. According to the European Federation of Cleaning Services (EFCI), in Norway daytime cleaning has become the rule and represents 80 per cent of total cleaning time (EFCI 2010), followed by Belgium, where about half of cleaning is done during daytime. In other countries, daytime cleaning remains extremely limited despite the fact that sector representatives see it as a desirable improvement in working conditions. They are, however, confronted by the reluctance of clients to have cleaners around during office hours.

Part-time work remains the most frequent form of employment in this sector and covers 70 per cent of the workforce in Europe (EFCI 2010:19). In theory, part-time work may be a mechanism for facilitating work-life balance, but in practice many of the jobs in office cleaning have working times that adapt poorly to the needs of family life. Working time arrangements in fact depend greatly on the sites workers are sent to and on their relationship with the front-line managers who make the work schedules (Holtgrewe and Sardadvar 2011). In addition, part-time work leads to jobs that hardly secure a viable income, despite the fact that collectively agreed hourly wages are not necessarily low for the type of workforce in this industry (mostly low-skilled groups) as compared with other lowwage sectors. 
A key trend that holds a high risk of deteriorating job quality is that contracts with clients are increasingly getting shorter and are being concluded for smaller volumes, which has a direct impact on the working conditions of cleaners. Being a highly labour-intensive sector, salaries are the most important cost and represent about 75 per cent to 80 per cent of total employer outlays (EFCI 2010). Consequently, this is where competition is the toughest. Cost reductions related to the awarding of contracts directly affect the economic margins of the cleaning contractors and this puts employment contracts, wages, working times and benefits under high pressure. Obviously, clients procuring cleaning services aim for costs to be reduced. This has been all the more true since cost reduction to increase competitiveness has become an increasingly important part of business strategies in both the private and public sectors (Lehndorff and Jaehrling 2012). Public procurement is growing all over Europe as a result of liberalization and privatization of public services, leading to more outsourcing, and nowadays this is combined with the increased budget restrictions and austerity programmes of public authorities (OECD 2011). There is some evidence that the fixation on price only, rather than on the quality of the services or on a combination of both, is intensified because of the economic and financial crisis (Petersen et al. 2011). According to Martinez (2010) and as confirmed in the WALQING research (for example Antentas 2011), a trend of constantly increasing rationalization is observed as a result. Despite the fairly comprehensive collective agreements overall, competition on wages mainly revolves around getting people to do the same type of job in fewer hours, which leads to a spiral of lower incomes and increasing work intensity. In addition, this rationalization affects not only employment conditions and collective bargaining margins, but also job quality itself.

A last development is indeed that in all countries cleaning activities have gradually undergone a process of what service providers themselves call 'professionalization', which in fact concerns a number of interventions to increase productivity: systematic implementation of sophisticated techniques and equipment (such as dry cleaning or ergonomic carts), increased use of standardized calculations and work method prescriptions based on detailed work analyses (for instance, the number of square metres that can be cleaned in different types of spaces) and specific training for cleaners. As a result, office cleaning is in no way comparable to cleaning at home. On the one hand, these new workplace practices may reduce specific health and safety risks such as back problems. On the other hand, however, they also lead to work intensification because they are directly related to productivity increases in a context of tougher contract negotiations and strong competition. The question now 
is at what levels and by what mechanisms job quality is regulated in the different countries under study.

\section{Regulating Job Quality in Office Cleaning}

\section{Employment Regulation at the Sectoral Level: The Cross-Country Convergence}

The cleaning sector has a well-structured social partnership at European level. Over the past few years, both EFCI and UNI-Europa have developed a number of initiatives such as the promotion of daytime work and the battle against undeclared work. In most of the old member states, including the three countries under study, social dialogue in cleaning is similarly well developed, as described in Table 14.3 (Adam 2012). The relative strength of sectoral collective bargaining structures, practices and outcomes is quite remarkable for the type of activities (low-skilled and standardized work, mostly part-time) and type of workforce (vulnerable groups) involved. This also contrasts highly with the mostly very weak representation structures and trade union power at client sites. Here, the fragmentation and spatial distribution of the workforce considerably complicates any form of trade union influence and collective action.

Further to the interviews with the social partners represented, two explanations stood out to explain the generally well-functioning sectoral social dialogue. A first explanation is the joint interest in combatting unfair competition, in particular by small and micro enterprises. These so-called junk enterprises (Torvatn 2011) operate at social dumping conditions and practice undeclared work, unpaid overtime, highly flexible contracts and working hours, low wages, and so on. As a result, competition on the cleaning services market is not on equal terms, and this harms the competitive position of the larger, well-regulated service providers. The very high turnover of these micro companies combined with the extremely low barriers to market entry (a number of buckets and brooms are sufficient to set up a cleaning company) make the battle against this type of competitor a neverending story.

The second and increasingly pertinent explanation is the alliance between unions and cleaning sector employers' federations to negotiate better contracts with clients. Here, the common goal is to base the awarding of contracts not only on price but also on the quality of the service 


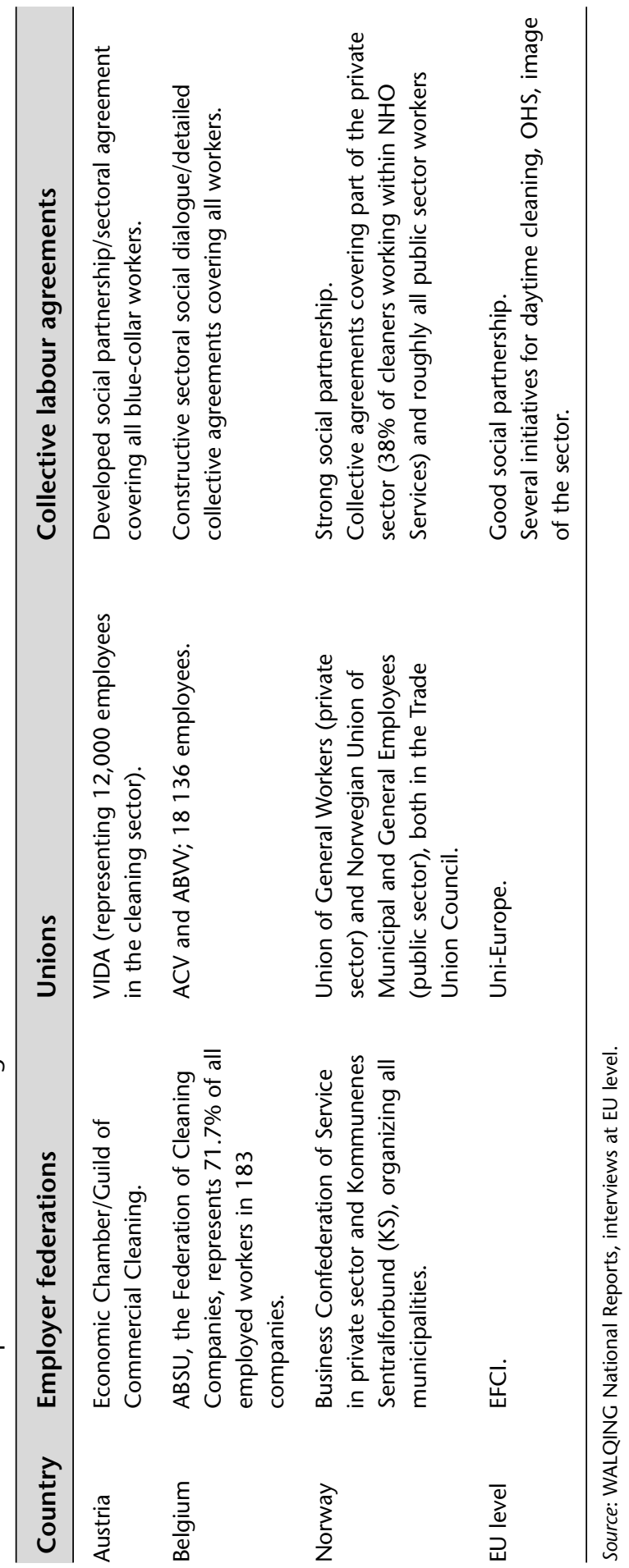


and to negotiate longer contracts (or to limit contract termination conditions). Increasingly, clients, including those from the public sector, seem to emphasize cost rather than quality of service and have an interest in the deregulation of contract conditions in order to more easily shift service contracts to a cheaper provider. Cheaper prices result in lower wages, minimal contractual obligations and flexible working times for the service provider's employees. The service providers, in contrast, realize they benefit from more regulation on these issues. Better contracts generate greater profits and contract regulations applicable to the entire sector stop the downward spiral of competition within the sector. Better contracts are obviously also to the benefit of the workers because they make it possible to limit work intensification and offer enhanced employment security, higher wages and better working time arrangements, and they justify investments in training. As one employer put it: 'The larger the pie, the bigger the pieces for everybody' (Pauwels and Ramioul 2011). Based on this common interest, the social partners for the cleaning sector lobby jointly to develop European regulations for public procurement. Further, at EU level and in different countries, they take part in several initiatives to better regulate the terms and conditions of contracts, for instance on new work methods reducing health and safety risks, on uniform standards for the time needed to clean similar square metres and on working times, as illustrated below. It came quite generally to the fore during the interviews in the three countries under study and at EU level that the crisis and austerity programmes to which the public authorities (which are very important clients) are subjected put even more pressure on contract negotiations. This reinforces the importance of building strong alliances between the sectoral social partners in response. Finally, the convergence observed across countries as regards this sectoral employment regulation can be explained by the fact that the employers' federations are dominated by large companies, which increasingly operate at international level (owing to continuous processes of capital concentrations and mergers and acquisitions).

In conclusion, as expressed by the sectoral social partners, strong alliances between trade unions and employer organizations are needed to provide a counter-tendency to the downward spiral of employment deregulation and fiercer competition, which are reinforced by the economic crisis. The social dialogue established as a response to this development has resulted in a number of sectoral regulations that mitigate some of the intrinsic risks for cleaning workers.

A first outcome commonly observed in different countries is the generalization of sectoral collective agreements to all companies belonging to the industry. Making collective agreements generally applicable is a 
system for establishing a uniform minimum level of wages and rights within a sector. In Norway, the respondents emphasized that this system makes it possible to prevent social dumping on wages in enterprises without collective agreements (Torvatn 2011). In Belgium too, generally applicable collective agreements have been concluded for the cleaning sector. A prime example of when such a generalization is beneficial both for the service provider and for the workers is in the case of a transfer of a service contract. When a client awards the service contract to another service provider, the cleaners are often transferred to the new service provider as well. When the new service contract is based on cheaper prices, this may worsen the employment conditions of the transferred workers. The generalized collective agreement secures the employment conditions for the workers involved because it regulates the transfer of acquired rights: the 'existing' employees can stay at the same site and for at least 6 months their working time schedules have to remain unchanged. This system is also beneficial for the service providers since it discourages clients from constantly renegotiating contractual conditions and shifting service contracts. In Austria, collective agreements ensure some job protection during contract renewals, but here it is reported that if contractors and their clients want to save on accrued claims for holiday pay or bonuses, they may use the change of contracts as an opportunity to replace employees (Holtgrewe and Sardadvar 2011).

A second example of convergence across the different countries is the joint promotion of daytime cleaning. Here, the social partners' initiatives at national level are strongly encouraged and supported by a joint declaration on daytime cleaning by the EU-level social partners of the cleaning sector (Uni Europa n.d.). In many countries, the debate about working time schedules is quite heated. While companies in Belgium and Austria face similar situations with regard to split shifts, which imply that cleaners have to work both in the morning and in the evening at the same site, and work at socially difficult hours in office cleaning, Norway has already successfully rendered daytime cleaning commonplace (Holtgrewe and Sardadvar 2012). The table of the WALQING case studies (Table 14.4) shows that in all cases daytime and fulltime work is the norm in Norway.

In Austria, the social partners have expressed a common interest in banning the practice of split shifts, albeit for different reasons. While the trade union wants to improve working conditions and work-life balance, the employers' association wants to improve recruitment and get rid of the additional labour costs linked to night shifts. Hence, an expansion of daytime cleaning would improve the quality of work considerably, albeit at the expense of some stagnation in the number of jobs. In this respect, 
Table 14.4 Contracts and working time arrangements in office cleaning

\begin{tabular}{|c|c|c|c|}
\hline $\begin{array}{l}\text { Case/ } \\
\text { country }\end{array}$ & Contracts & $\begin{array}{l}\text { Amount of working } \\
\text { time }\end{array}$ & $\begin{array}{l}\text { Working } \\
\text { hours }\end{array}$ \\
\hline $\begin{array}{l}\text { CLEANCOMP } \\
\text { AT }\end{array}$ & $\begin{array}{l}\text { Open-ended } \\
\text { contracts with short } \\
\text { period }\end{array}$ & $\begin{array}{l}\text { Usually part-time; contracted } \\
\text { notice hours regularly } \\
\text { adapted of to hours actually } \\
\text { worked }\end{array}$ & $\begin{array}{l}\text { Peaks } 6-9 \text { a.m. } \\
\text { and } 4-8 \text { p.m.; } \\
\text { often split } \\
\text { shifts }\end{array}$ \\
\hline $\begin{array}{l}\text { LARGECLEAN } \\
\text { AT }\end{array}$ & $\begin{array}{l}\text { Permanent contracts } \\
\text { with short period of } \\
\text { notice }\end{array}$ & $\begin{array}{l}23 \% \text { fulltime ( }=40 \text { hours), } \\
\text { part-time on average } \\
20 \text { hours }\end{array}$ & $\begin{array}{l}\text { Often split } \\
\text { shifts, } \\
\text { mornings, } \\
\text { evenings }\end{array}$ \\
\hline $\begin{array}{l}\text { CENTIPEDE } \\
\text { BE }\end{array}$ & $\begin{array}{l}\text { Blue-collar workers on } \\
\text { permanent contracts }\end{array}$ & $\begin{array}{l}\text { Standard time } 37 \text { hours; } \\
\text { majority works part-time }\end{array}$ & $\begin{array}{l}\text { Often split } \\
\text { shifts }\end{array}$ \\
\hline $\begin{array}{l}\text { MUNICLEAN } \\
\text { NO }\end{array}$ & $\begin{array}{l}\text { Majority on open- } \\
\text { ended contracts }\end{array}$ & $\begin{array}{l}\text { Majority full-time; part-time } \\
\text { on worker's demand }\end{array}$ & Daytime \\
\hline $\begin{array}{l}\text { REGIOCLEAN } \\
\text { NO }\end{array}$ & $\begin{array}{l}\text { All on permanent } \\
\text { contracts (after a 6- } \\
\text { month probation } \\
\text { period) }\end{array}$ & $\begin{array}{l}\text { Most cleaners work } \\
80 \%-100 \% \\
(37.5 \text { hours/week) }\end{array}$ & Daytime \\
\hline $\begin{array}{l}\text { BIGCLEAN } \\
\text { NO }\end{array}$ & $\begin{array}{l}80 \% \text { permanent } \\
\text { employees }\end{array}$ & 6 hours/day on average & Daytime \\
\hline
\end{tabular}

Source: Based on Holtgrewe (2012).

Austrian sectoral stakeholders ask for more policy support for their joint desire to promote daytime cleaning, especially since the public sector represents a large share of the customer base (Holtgrewe and Sardadvar 2011). In Belgium, trade unions have initiated the promotion of daytime cleaning in collaboration with the employers' association ABSU. Both the sector's employers' organization and the trade unions admit that it will always be difficult to prevent some clients from requiring that cleaning staff remain 'invisible' to their employees (Pauwels and Ramioul 2011). Nevertheless, ABSU acknowledges that splitting working hours can be hard for workers and costly to employers. The joint action included raising awareness about the benefits of daytime cleaning among the broader public, for instance by posting a related message on public transport (buses in all large cities) and public places and by distributing leaflets. With this joint action, the social partners wanted to convince clients and their employees of the advantages of working during the day: companies are more accessible by public transport, less energy is wasted for heating when cleaning during the day, fewer security personnel are required, and the safety of cleaning staff improves. 


\section{Persistent Differences in Job Quality Across Companies}

Next to these similarities, and to the growing convergence of sector-level collective bargaining, both at the EU level and across the three countries studied, the case studies also exposed considerable differences in working conditions between countries and companies. As regards the generalized working times in Norway as illustrated above, this was most strikingly illustrated when we compared the work organization and skill formation strategies between different subsidiaries, a Belgian and a Norwegian one, of a large transnational service provider. In Belgium, one the largest employers of facilities services, nicknamed 'Centipede', was in the middle of a so-called 'cleaning professionalization programme' at the moment of the investigation. This involved the generalized use of new ergonomic equipment aimed at alleviating certain ergonomic risks, such as lifting heavy buckets full of water. But the programme involved most of all a comprehensive analysis of all operations leading to detailed and standardized prescriptions and a far-reaching fragmentation of cleaning tasks. This was accompanied by the calculation of strict timeframes for each of the short-cycled operations. In this process the cleaning procedures were completely redesigned, leading to less interesting work: rather than letting a small team jointly do all the cleaning tasks for each office, the work was distributed differently. One cleaner was responsible for emptying the waste bins of all offices, the other for doing (only) all writing desks, a third did nothing but dust, and so on. Furthermore, the role of 'team leader' was now reduced from that of a frontline manager responsible for organizing and distributing the work among the different teams to that of a simple supervisor watching the correct execution of the prescribed tasks.

Since the company investigated in Norway belonged to the same transnational service provider, we were able compare the new workplace practices promoted in the two countries. The Norwegian subsidiary used the same new cleaning technology and equally changed their cleaning methods and work organization. However, the latter contrasted greatly with the Belgian practices. In Norway, the company adopted advanced forms of teamwork and employee involvement schemes. Here, tasks were deliberately broadened and organized in teams. The team leader had a farreaching autonomy to distribute the work among the team members and only the aggregate time schedules had to be respected. Every morning, the team leaders discussed the daily distribution of work with all the cleaners at the site. This enabled much more variation in tasks and assignments, leading to more interesting work and learning opportunities. As a consequence, it was also recognized that cleaning requires a specific set of 
skills and that, consequently, investments in training are justified. This also led to increased wage levels and a higher status.

This case shows a stark contrast between the low-road strategy based on taylorism in the Belgian subsidiary and the high-road strategy based on teamwork in the Norwegian one. This on the one hand confirms the point made by Vidal $(2011,2013)$ that postfordist regulation regimes, to which all the three countries involved in the study belong, continue to generate a structural demand for low-autonomy work as a result of the profit-driven social division of labour. Not only does the job quality deteriorate in terms of wages and contracts because of externalization; these new jobs are also characterized by high work intensity, low skills levels and poor training investments. On the other hand, it appears that in individual organizations jobs are still configured in a variety of ways. Vidal refers to these variations as resulting from the 'cultural framing of the situation' by managers when they adopt a logic of substantive empowerment (Vidal 2013). In the study at hand, these differences between subsidiaries across countries can be related to the fact that the Norwegian corporate strategy is fully in line with the Scandinavian tradition of highinvolvement workplaces and the historical endorsement of the importance of good job quality to competitiveness at the national level by both employer organizations and trade unions. In Norway, the awareness of the importance of good job quality is embedded in the social dialogue and is an essential element in industrial relations practices (Finnestrand and Ravn 2011). Such a 'national compromise on job quality' is absent in the institutionalized employment regulation in Belgium. Here, social partners at different levels have historically limited the quantitative redistribution of productivity increases to the improvement of employment conditions (wages and working times) and purchasing power, and have seen this as the cornerstone of the fordist compromise, while the design of the labour process remains almost entirely the competence of the employer (POLEKAR 1985; De Volder 2003).

\section{Conclusion}

The cleaning industry provides a strong example of an increasingly complex interplay between national, sectoral and organizational employment regulation. As a service industry, it is clear that the growth of the sector can to an important extent be explained by the tendency of organizations to reduce their costs by externalizing non-core business activities to companies that operate more cheaply by offering lower job security, less fulltime work, more flexible working times and lower wages. Since 
this trend can be observed all over Europe and in different employment regimes, such externalization contributes to a growing divergence in working conditions within countries. At the same time, the sectoral regulation in the cleaning industry shows remarkable similarities across countries. The aim of combating unfair competition by small companies operating at the edge of legality is an important driver for alliances between trade unions and employer federations. The growing globalization and concentration among large service providers persistently faced with the social dumping practices of a constantly renewing number of often ephemeral micro companies is a first explanation of this convergence across countries. A second explanation is found in the fact that in the triangular relationship (between workers, service providers and clients) trade unions and service provider employer federations have common interests as well. The difficulty involved in setting up a proper social dialogue for cleaners at the client's site plays a key role in this respect. At the local sites, it is extremely difficult to set up a powerful employee representation and develop strategies that effectively improve working conditions. The local site manager, as the client, has an overwhelming say in how and under what conditions work is actually done. The coexistence of weak workplace representation and similarly weak onsite bargaining positions on the one hand, and a powerful and effective sectoral social dialogue on the other, is not a contradiction but is precisely induced, and can be explained, by the triangular relationship (Denis 2008). The common interest between the trade unions and employer federations of service providers is rooted in the fact that better contracts, and contract-awarding procedures, are to the benefit of both parties. Their alliance is reflected in a range of collective agreements that regulate employment conditions for all operating companies. Various such initiatives explicitly address job quality issues, such as the promotion of daytime work. Others have indirect impacts on job quality, such as the common position against the principle of the most advantageous economic offer in contract awarding (public procurement) or the transferring of acquired rights. It has also come to the fore that these alliances are reinforced as a response to increasing pressure on service contracts due to the economic crisis.

Two important qualifications have to be made with respect to this observed cross-country convergence. First, sectoral regulation does not fully prevent a deterioration of working conditions for externalized jobs, as the persistent use of part-time work, difficult working times and low wages in cleaning demonstrate. Hence, the employees of service providers are likely to end up with worse working conditions than the employees of their clients to whom their jobs originally belonged. This supports the 
argument of a growing within-country divergence that accompanies the growing cross-country sectoral convergence. On the other hand, the cases also demonstrate that the national employment system, institutions and practices still play their role in setting standards for all workers. In other words, the national systems still can make the difference in the outcome for the workers when job quality is compared cross-nationally. This became quite clear from looking at the standards in Norway concerning fulltime work, daytime cleaning, work organization design and training investments. Second, sectoral regulations do not completely prevent differences existing between companies in any given sector within a country. The key role of the client in determining when and under what conditions the work is done appears to be an obstinate factor working against attempts to achieve homogeneous and generally applicable regulations through sectoral bargaining. The seemingly ineradicable presence of deregulated micro companies in the market of service provision obviously plays a role here. Generally speaking, clients still emphasize price rather than quality of service, they shorten contract durations in order to be able to easily renegotiate contractual conditions, and, where possible, they prefer not to have cleaners around during office hours. These observations indicate that competitiveness between companies may still triumph over the power of sectoral social dialogue.

\section{Notes}

1 Work and Life Quality in New and Growing Jobs (WALQING), financed under the EC 7FP RTD (SSH-CT-2009-244597), carried out by a consortium of 12 research institutions from $11 \mathrm{EU}$ member states between December 2009 and November 2012.

2 UNI-Europa is a European trade union federation. It unites trade unions organizing in services and skills sectors in 50 different countries. With over 320 affiliated trade union organizations, UNI-Europa represents 7 million workers, including from the cleaning sector.

\section{REFERENCES}

Adam, Georg (2012) Representativeness of the European Social Partner Organisations: Cleaning Activities Industry. Dublin: European Foundation for the Improvement of Living and Working Conditions.

Antentas, Josep M. (2011) 'INTERCLEAN: A Cleaning Case Study from Spain', Internal Report for WP6 of the Walqing project, SSH-CT-2009-244597. Barcelona. 
$>$

Bacon, Nicolas and Paul Blyton (2000) 'High Road and Low Road Teamworking: Perceptions of Management Rationales and Organizational and Human Resource Outcomes', Human Relations 53, 11:1425-58.

Bolton, Sharon C. and Maeve Houlihan (2010) 'Bermuda Revisited? Management Power and Powerlessness in the Worker-Manager-Customer Triangle', Work and Occupations 37, 3:378- 40.

Denis, Jean-Michel (2008) Les Relations professionnelles dans le secteur du nettoyage. Du syndicalisme en milieu précaire (The Professional Relations in the Cleaning Sector. Trade Unionism in a Precarious Environment), Document de travail. Paris: IRES.

Devolder, Conny (2003) 'Een Belgische "Sonderweg" De sociopolitieke agenda van het ondernemingssyndicalisme (1937-1959)' (A Belgian 'Sonderweg'? The Sociopolitical Agenda of Corporate Trade Unionism (1937-1959), Belgisch Tijdschrift voor Nieuwste Geschiedenis/Revue Belge d'Histoire Contemporaine xxxII, vol. 3-4, pp. 577-641. Gent: Jan Dhondtstichting.

Dörrenbächer, Christoph (2002) National Business Systems and the International Transfer of Industrial Models in Multinational Corporations: Some Remarks on Heterogeneity. Discussion paper, Wissenschaftszentrum Berlin für Sozialforschung, Forschungsschwerpunkt Arbeitsmarkt und Beschäftigung, Abteilung Organisation und Beschäftigung, No. FS I 02-102.

EFCl. (2010) The Cleaning Industry in Europe: An EFCI Survey. Brussels.

Finnestrand, Hanne O. and Johan E. Ravn (2011) 'The Duality Between Generous and Demanding Work: BIGCLEAN - a Cleaning Case Study from Norway', Internal Report for WP6 of the WALQING project, SSH-CT-2009-244597. Trondheim.

Flecker, Jörg (2010) 'Fragmenting Labour: Organisations Restructuring, Employment Relations and the Dynamics of National Regulatory Frameworks', Work Organisation Labour and Globalisation 4, 1:8-23.

Flecker, Jörg. et al. (2006) Restructuring Across Value Chains and Changes in Work and Employment. Leuven: HIVA.

Hall, Peter A. and David Soskice (2001) 'An Introduction to Varieties of Capitalism', pp. 1-70 in Varieties of Capitalism: The Institutional Foundations of Comparative Advantage, edited by Peter A. Hall and David Soskice. Oxford University Press.

Herrigel, Gary (1996) 'Industrial Constructions: The Sources of German Industrial Power. Structural Analysis', Structural Analysis in the Social Sciences Series, Book 9. Cambridge University Press.

Herrigel, Gary and Jonathan Zeitlin (2010) 'Alternatives to Varieties of Capitalism', Business History Review 84, 4:667-74.

Hohnen, Pernille (2012) 'Capacities and Vulnerabilities in Precarious Work. The Perspective of Employees in European Low Wage Jobs', Synthesis Report on Employees' Experience And Work Trajectories for Work Package 7 of the WALQING Project, SSH-CT-2009-244597. Roskilde University, Copenhagen

Hollingsworth, J. and R. Boyer (eds) (1997) Contemporary Capitalism: The Embeddedness of Institutions. Cambridge University Press.

Holtgrewe, Ursula and Karen Sardadvar (2011) 'The Commercial Cleaning Sector in Austria: Social Partnership in Unlikely Places,' Walqing Social Partnership Series 2011.1, WALQING project, SSH-CT-2009-244 


\section{$\checkmark$}

Holtgrewe, Ursula and Karen Sardadvar (2012) 'Hard Work. Job Quality and Organisation in European Low-Wage Sectors', Synthesis Report on Company Case Studies for Work Package 6 of the WALQING Project, SSH-CT-2009244597. Vienna.

Katz, Harry C. and Owen Darbishire (1999) Converging Divergences: Worldwide Changes in Employment Systems, Ithaca, NY: ILR Press/Cornell University Press.

Kirov, Vassil (2011) 'How Many Does It Take to Tango? Stakeholders' Strategies to Improve Work in Europe', WALQING Project, SSH-CT-2009-244597. Sofia.

Korczynski, Marek (2009) 'The Mystery Customer: Continuing Absences in the Sociology of Service Work', Sociology 43, 5:952-67.

Korczynski, M., K. Shire, S.J. Frenkel and M. Tam (2000) 'Service Work in Consumer Capitalism: Customers, Control and Contradictions', Work, Employment and Society 14, 4:669-87.

Lehndorff, Steffen and Karen Jaehrling (2012) 'Anchors for Job Quality: Policy Gaps and Potentials', Final Report of Work Package 8 and Deliverable 8.9 ('Report on Possibilities and Gaps of (Stakeholder and State) Policies') of the WALQING Project, SSH-CT-2009-244597. University of Duisburg-Essen.

Leidner, Robin (1996) 'Rethinking Questions of Control: Lessons From Mcdonald's', pp. 29-49 in Working in the Service Society, edited by C.L. Macdonald and C. Sirianni. Philadelphia, PA: Temple University Press:.

Lopez, Steven (2010) 'Workers, Managers, and Customers: Triangles of Power in Work Communities', Work and Occupations 37, 3:251-71.

Martinez, Esteban (2010) Les Salariés à l'épreuve de la flexibilité. Editions de I'Université de Bruxelles.

OECD (2011) Government at a Glance 2011. Geneva: OECD.

O'Riain, Sean (2010) 'The Missing Customer and the Ever-Present Market Software Developers and the Service Economy', Work and Occupations 37, 3:320-48.

Pauwels, Fernando and Monique Ramioul (2011) 'Quality of Work in Belgium's Cleaning Industry: Intrinsic Risks and Sectoral Regulation', Walqing Social Partnership Series 2011.3, WALQING Project, SSH-CT-2009-24

Petersen, Ole Helby, Ulf Hjelmar, Karsten Vrangbæk and Lisa la Cour (2011) Effects of Contracting Out Public Sector Tasks: A Research-Based Review of Danish and International Studies from 2000-2011, AKF:128. Copenhagen: Danish Institute of Governmental Research.

POLEKAR (1985) Het laboratorium van de crisis: debat over een nieuwe maatschappelijke ordening (The Laboratorium of the Crisis: Debate About a New Societal Order). Leuven: Acco.

Quack, Sigrid and Glenn Morgan (2000) 'National Capitalisms, Global Competition and Economic Performance: An Introduction', pp. 3-25 in National Capitalisms, Global Competition and Economic Performance, edited by Sigrid Quack, Glenn Morgan and Richard Whitley. Amsterdam: John Benjamins.

Torvatn, Hans (2011) 'Cleaning in Norway - Between Professionalisation and Junk Enterprises', Walqing Social Partnership Series, WALQING Project, SSH-CT-2009244597. Trondheim. 
UNI Europa (s.d.) Joint Declaration on Daytime Cleaning, available at http://ec.europa.eu/employment_social/dsw/public/actRetrieveText.do?id=113 64, accessed 13 June 2013.

Vandekerckhove, Sem, Bart Capéau and Monique Ramioul (2010) 'Structural Growth of Employment in Europe: Balancing Absolute and Relative Trends', WALQING Working Paper, WALQING Project, SSH-CT-2009-244597. Leuven.

Vidal, Matt (2011) Reworking Postfordism: Labor Process Versus Employment Relations, Sociology Compass 5, 4:273-86.

Vidal Matt (2013) 'Low-Autonomy Work and Bad Jobs in Postfordist Capitalism', Human Relations 66, 4:587-612.

Vosko, Leah F. (1997) 'Legitimizing the Triangular Employment Relationship: Emerging International Labour Standards from a Comparative Perspective', Comparative Labor Law and Policy Journal 19:43-77.

Whitley, Richard (1992) Divergent Capitalisms: The Social Structuring and Change of Business Systems. Oxford University Press. 